\title{
Corruption and mismanagement in spending on education: socioeconomic and political factors
}

\author{
Daniele Silva Rodrigues ${ }^{1}$ \\ Walmer Faroni 2 \\ Nálbia de Araújo Santos 2 \\ Marco Aurélio Marques Ferreira ${ }^{2}$ \\ Josedilton Alves Diniz ${ }^{3}$ \\ 1 Universidade Federal de Minas Gerais / Centro de Pós-graduação e Pesquisas em Controladoria e Contabilidade, \\ Belo Horizonte / MG - Brazil \\ 2 Universidade Federal de Viçosa / Programa de Pós-Graduação em Administração, Viçosa / MG - Brazil \\ 3 Universidade Federal da Paraíba / Programa de Pós-Graduação em Ciências Contábeis, João Pessoa / PB - Brazil
}

This research analyzes the socioeconomic and political factors that influence the occurrence of corruption and mismanagement in public spending on basic education in Brazilian municipalities. The sources of data were the inspection reports of the Comptroller General of the Union during 2011 to 2015; and the websites of the Federation of Industries of the State of Rio de Janeiro, the Brazilian Institute of Geography and Statistics, the Superior Electoral Court, and the National Treasury Secretariat. The data analysis adopted descriptive procedures and binomial negative regression. Overall, the results indicate that the possibility of reelection of the mayor and the performance of municipal councils affected the incidence of corruption. In turn, an occurrence of mismanagement shows a significant relationship with the voter's profile and the performance of municipal councils. These findings highlighted the relevance of municipal councils as an instrument for monitoring and supervising public spending on basic education of Brazilian municipalities.

Keywords: corruption; mismanagement; basic education.

\section{Corrupção e má gestão nos gastos com educação: fatores socioeconômicos e políticos}

O objetivo desta pesquisa foi analisar os fatores socioeconômicos e políticos que influenciaram a ocorrência de corrupção e má gestão nos gastos com o ensino básico nos municípios brasileiros. As fontes de dados usadas foram os relatórios das fiscalizações realizadas pela Controladoria-Geral da União (CGU) de 2011 a 2015 e os websites da Federação das Indústrias do Estado do Rio de Janeiro (FIRJAN), do Instituto Brasileiro de Geografia e Estatística (IBGE), do Tribunal Superior Eleitoral (TSE) e da Secretaria do Tesouro Nacional (STN). Os dados foram analisados por meio de procedimentos descritivos e regressão Binomial Negativo. De modo geral, os resultados indicaram que a possibilidade de reeleição do prefeito e a atuação dos conselhos municipais afetaram significativamente a incidência de corrupção. Por sua vez, a ocorrência de má gestão apresentou relação significativa com o perfil do eleitor e atuação dos conselhos municipais. Esses achados destacam a relevância dos conselhos municipais como instrumentos de acompanhamento e fiscalização da aplicação dos recursos públicos destinados ao ensino básico nos municípios brasileiros.

Palavras-chave: corrupção; má gestão; ensino básico.

\section{Corrupción y mala gestión en los gastos en educación: factores socioeconómicos y políticos}

El objetivo de esta investigación es analizar los factores socioeconómicos y políticos que influenciaron el surgimiento de corrupción y de mala gestión de los gastos en enseñanza básica en los municipios brasileños. Las fuentes de datos utilizadas fueron los informes de las fiscalizaciones realizadas por la Contraloría General de la Unión entre los años 2011 a 2015; y los sitios web de la Federación de las Industrias del Estado de Río de Janeiro, del Instituto Brasileño de Geografía y Estadística, del Tribunal Superior Electoral y de la Secretaría del Tesoro Nacional. Para el análisis de los datos se realizaron procedimientos descriptivos y la regresión binomial negativo. En general, los resultados indicaron que la posibilidad de reelección del alcalde y el desempeño de los consejos municipales afectaron significativamente la incidencia de la corrupción. A su vez, la mala gestión mostró una relación significativa con el perfil del votante y el desempeño de los consejos municipales. Estos hallazgos destacan la relevancia de los consejos municipales como instrumento de seguimiento y fiscalización de la aplicación de los recursos públicos destinados a la enseñanza básica de los municipios brasileños.

Palabras clave: corrupción; mala gestión; enseñanza básica. 


\section{INTRODUCTION}

Article 205 of the 1988 Brazilian Constitution provides that education is a right of every Brazilian, guaranteed by the state (CF, 1988). The state has the duty of creating egalitarian and universal public policies to deliver education services, and the organization and funding of the country's education structure were distributed among the different levels of government (federal, state, the federal district, and municipal governments) (CF, 1988). The Brazilian system is organized in pre-school, primary school, high school, and higher education.

Basic education (pre-school, primary school, and high school) is tuition-free and offered to all citizens. The service provision is decentralized to the states, the Federal District, and the municipalities. However, section 1 of art. 211 of the 1988 Brazilian constitution states that the Union must "guarantee the equal opportunity of education and a minimum quality standard by providing technical and financial assistance to states, the federal district, and municipalities."

Therefore, the federal government transfers earmarked funds to state and local governments to fulfill the constitutional duties related to basic education. The national education system counts on a fund for the maintenance and development of basic education and for the improvement of professionals working on education (Fundeb). There is a fund for each state where federal, state, and local governments deposit the amounts designated to finance basic education. As well as the usual transfers, the federal government deposits resources every time a state does not match the legal minimum amount to be invested per student enrolled in basic education (CF, 1988; Fundo Nacional de Desenvolvimento da Educação [FNDE], 2007).

It is possible to observe that, in recent decades, there has been a considerable increase in the funds transferred to basic education. In 2000, according to data from the National Institute of Educational Studies and Research Anísio Teixeira (INEP), the Union transferred to states and municipalities the amount of BRL 28.28 per student/year enrolled in basic education. This transfer increased to BRL 83.08 per student/year in 2014, which represents a growth of 163.60\% (Instituto Nacional de Estudos e Pesquisas Educacionais Anísio Teixeira [INEP], 2014).

However, even after the expansion of public investment, the OECD's "Programme for International Student Assessment" (PISA) in 2015 showed that Brazil had one of the worst performances among the participant countries for the last ten years. The results are below the average achieved by countries such as Chile, Mexico, Costa Rica, Uruguay, and Colombia (INEP, 2016; Organisation for Economic Co-Operation and Development [OECD], 2016).

An explanation for this result may be the waste of resources due to corruption and mismanagement in the implementation of public policies. According to Ferraz, Finan, and Moreira (2008), corruption and mismanagement in the investment of federal resources on basic education in Brazil negatively affect the results of programs in the area, leading to low-quality in the services provided. Moreover, according to the Office of the Comptroller General (CGU), education is one of the sectors most vulnerable to misuse of public resources (Controladoria-Geral da União [CGU], 2016).

Corruption and mismanagement by public agents seriously damage Brazilian public education. It is crucial, therefore, to identify the aspects that favor dishonesty and the uneconomical behavior of public agents when applying federal resources for basic education. 
Recent empirical studies on the waste of public resources suggest the influence of socioeconomic and political aspects in the public agents' environment. In a study in Brazilian municipalities focusing on misconduct in public procurement in the area of health, Laurinho, Dias, and Mattos (2017) found evidence that municipalities with lower human development index (HDI) were more susceptible to corruption and mismanagement. In the international context, Benito, Guillamón, Ríos, and Bastida (2018) researched municipalities in Spain, concluding that corruption is less likely to occur in political contexts where there is the possibility of public officials' reelection.

However, there is a gap in the literature regarding the factors involved in public spending on education. The studies mentioned above did not address the characteristics of public agents' corruption and mismanagement practices toward spending on education. Also, the studies did not analyze the relationship between these conducts and the agents' socioeconomic and political environment.

Against this backdrop, this study seeks to answer the following research question:

- What is the relationship between the socio-economic and political profile of Brazilian municipalities, and the corruption and mismanagement regarding spending on basic education in the country?

Therefore, the study analyzes the Brazilian municipalities' spending on basic education, observing the socioeconomic and political factors that influence corruption and mismanagement. The research focused on the implementation of the Programa Nacional de Apoio ao Transporte Escolar (PNATE) (a national program of school transportation), the Programa Nacional de Alimentação Escolar (PNAE) (national school feeding program), and the Fundeb. These programs were selected based on the evaluation of the CGU (2016), which considered them the most vulnerable for resource misappropriation.

\section{THEORETICAL FRAMEWORK}

This article assumes that corruption and mismanagement have particular characteristics, and understands them as a waste of resources due to, among other factors, low or questionable performance of public agents implementing public policies.

As for corruption, the organization Transparency International (2018), defines it as the abuse of entrusted power for private gain. Mismanagement, in turn, concerns the waste of public resources where the public agent does not obtain advantages (personally or to a third party). The waste occurs because of the public agent's negligence or lack of preparation toward best practices in management (Ferraz, Finan, \& Moreira, 2012; Sodré \& Alves, 2010).

Public agent refers both to elected officials (politicians) and bureaucrats. However, different incentives and limits shape the behavior of these actors.

Because they submit to the electoral process to gain and maintain power, politicians observe the voters' preferences and are guided by political interests. Bureaucrats do not have to submit to such a process to remain in the public sphere. Their decisions, therefore, are more likely to be guided by technical aspects (Rua \& Aguiar, 1995).

It is important to clarify that, when mentioning 'public agents', this study is referring to politicians. The rationale is that these actors are responsible for decisions that lead to unnecessary public spending, 
even though the bureaucrats may be the ones to carry out the tasks related to implementing such expenses. In other words, politicians guide and monitor the work of bureaucrats in the management of public resources.

The theory subsidizing the analysis presented here is Public Choice (PCT), which helps to understand the political agents' behavior regarding public spending, as well as to discuss the factors that may influence such behavior.

\subsection{Public Choice Theory}

According to Borsani (2004), the Public Choice Theory (PCT), assumes that political and private agents have the same motivations. In this approach, their decisions are influenced by individual goals and not by public interest. For Shughart (2007), however, there are differences between the choice process in the public and private sectors, since there are different incentives and constraints between them.

Borsani (2004, p. 105) argues that the public sector is distinct because the agent's discretionary power (which would allow one to obtain personal advantages) is conquered exclusively through "competitive elections, with uncertain results, defined by the largest number of votes." In this context, the opinion of the voter is an essential feature of the public environment that influences the agents' public decisions.

In addition to the factors that can influence the process of public choice, the PCT emphasizes the practice of rent-seeking in the public sphere. For Borsani (2004), rent-seeking is the behavior where economic agents work to obtain privileges from government and markets profiting from the wealth that is already created. According to Silva (2001), the behavior of agents trying to maximize wealth outside legal parameters and adopting corruption practices is only possible because of the imperfections in the rules established around the relationship between the economic agent and the government. Therefore, public officials may use their position to grant privileges to private agents in exchange for illegal gains (bribery, for instance) (Borsani, 2004; Silva, 2001).

Finally, considering that the waste of public resources is a result of public managers' decisions, it is possible to assume that controlling the incidence of corruption and mismanagement depends mainly on the moral constraint of these actors and the increasing attention of society toward their behavior while in the public office. Thus, an analysis of the factors that influence the occurrence of public resources misuse has to take into account the political and socioeconomic factors around the public agents' behavior.

\subsection{Empirical evidence}

There are many empirical studies on corruption and mismanagement of public resources in the literature. In the international context, Del Monte and Papagni (2007) analyzed the causes of the different levels of corruption observed in regions of Italy, using the database on crimes against public administration, from 1963 to 2000. The main findings were that economic factors (such as public spending and level of economic development), political and cultural factors (such as competition 
among political parties, the presence of voluntary organizations, and absenteeism in national elections) significantly affected corruption in that country.

Lio, Liu, and $\mathrm{Ou}$ (2011) found a significant and negative relationship between the level of Internet use and the Transparency International's Corruption Perception Index, which is based on a sample of 70 countries, using data of the period from 1998 to 2005. For the authors, "the internet can play a substantial role in combating corruption by improving the enforcement of rules, lessening the discretion of officials, and increasing transparency" (Lio et al., 2011, p. 53).

Benito et al. (2018) studied the influence of politicians' salaries and their intention to seek reelection, in the level of corruption in 358 Spanish municipalities from 2004 to 2009. Evidence indicated that the higher the salaries of politicians, the greater the incentive for corruption. On the other hand, these authors noted that the possibility of reelection worked as an effective mechanism to reduce corruption in municipalities of Spain.

In Brazil, stand out the studies by Albuquerque and Ramos (2006), Ferraz and Finan (2011), Lopes (2011), Vieira (2011), Batista (2013), Campos and Castelar (2013), Dias (2016), and Laurinho et al. (2017). These authors focused on irregularities in the management of federal resources in municipalities, found by the auditors from the Office of the Comptroller General (CGU) (n.d.) under the Programa de Fiscalização por Sorteios Públicos (PFSP) (program of inspection based on random selection).

Albuquerque and Ramos (2006) investigated the main determinants of the fraudulent behavior of 503 mayors from 2003 to 2005 . The results suggest that: a) individuals are more likely to engage in corrupt acts when perceiving lower wages and enjoying greater discretionary powers; b) the possibility of reelection works as a barrier for corruption in an agent's first term in office; c) municipalities led by women tend to present higher level of illicit acts; and d) high-income and educated populations are more likely to inhibit the misuse of public resource since they are better equipped to supervise municipal managers.

Ferraz and Finan (2011) studied corruption concerning the possibility of reelection observing mayors in 496 municipalities during 2003 and 2004. The authors found that mayors in the first term tend to be less corrupt. According to the authors, the possibility of reelection reduces the corrupt behavior of mayors. Also, they found that corruption is accentuated in municipalities with restricted access to information and where punishment is less likely to occur.

Batista's (2013) findings corroborate the results of the studies by Albuquerque and Ramos (2006) and Ferraz and Finan (2011). The author analyzed 710 municipalities, inspected by the CGU in 2003 and 2004, and found that mayors in the second term and those elected with the highest votes tend to practice more corrupt acts.

Vieira (2011) sought to identify the factors that contributed to the occurrence of corruption in 840 municipalities inspected by the CGU in 2006 and 2009. The author observed a negative relationship between corruption and the variable 'checks \& balances' (a proxy for the states' institutional capacity of exercising control). Also, the study found that the incidence of corruption was higher in the North and Northeast regions of Brazil, which was attributed to the low indicators of municipalities' institutional capacity of exercising control. 
Campos and Castelar (2013) analyzed 1,623 municipalities inspected by the CGU between 2003 and 2010. There was evidence that municipalities that tend to present corruption cases are those where a) federal transfers represent a higher percentage of their budget; b) present weak social accountability; c) show a low municipal development; d) are neighbors of municipalities with corruption problems; and e) do not have low population density.

Lopes (2011), Dias (2016), and Laurinho et al. (2017) explored the occurrence of corruption and mismanagement in the application of resources in the area of public health. Lopes (2011) analyzed the impact of the characteristics of health care public policies; the institutional characteristics of municipalities; and the public agency training programs; on the incidence of corruption. The evidence showed that the incidence of corruption was lower in municipalities whose public agents were trained in legislation and compliance in the application of public resources.

Among the results of the study by Dias (2016), stand out the significant effects on the likelihood of corruption and mismanagement of the following factors: a) political-administrative region to which the municipalities belong; b) income and expenditure levels; and c) performance of the Municipal Health Council. The findings of the research by Laurinho et al. (2017) indicated that municipalities with lower HDI were more susceptible to corruption and inefficiency in public procurement.

\subsection{Hypotheses}

In general, the studies mentioned indicated that socioeconomic and political factors influence the occurrence of corruption and mismanagement in public spending, corroborating the assumptions of Public Choice Theory (PCT). Therefore, there is evidence to believe that municipal public managers in Brazil consider electoral circumstances and the opinion of voters before authorizing unnecessary expenses regarding the resources designated to basic education.

Also, the literature supports the assumption that public officials in local governments, when there is the possibility of reelection, are less likely to engage in irregularities, seeking to preserve their political image for the next election. Due to its level of uncertainty, an electoral race endangers the politician's ambition to remain in power and enjoy the benefits this condition entails.

Therefore, there are elements to consider the following hypotheses:

$\mathbf{H}_{1}$ : Corruption and mismanagement in public spending on basic education are positively related to municipalities managed by mayors in their second term.

$\mathbf{H}_{2}$ : The greater the electoral competition, the lower the incidence of corruption and mismanagement related to public spending on basic education.

The literature also indicated that the voters' opinion about a public agent would influence this agent's decision-making on public spending. However, it is noteworthy that voter behavior is influenced by their social context (Figueiredo, 2008).

Thus, the perception of voters about electoral candidates' behavior tends to vary according to voters' degree of "political sophistication." As a result, voters with low political sophistication may 
have a distorted view of the politician's behavior (Carreirão, 2000; Pereira, 2013). According to Pereira (2013), political sophistication is associated with the voters' socioeconomic status.

Voters are not always able to stay informed about the behavior of politicians, and an educated population is more likely to stay informed and denounce irregularities from political leaders. Therefore, it is possible to build the following hypothesis:

$\mathbf{H}_{3}$ : In municipalities where voters are more educated and perceive higher income, there is a lower incidence of corruption and mismanagement regarding public spending on basic education.

Finally, although voters can process information about the behavior of elected politicians, such information has to be accessible. In Brazil, civil society can participate in political decisions through councils, public ombudsmen offices, conferences, hearings, and public consultations (Pires \& Vaz, 2012).

These mechanisms of participation are particularly interesting for this study especially the role of legally mandatory councils such as the Conselhos Municipais de Alimentação Escolar (CAE) (municipal school feeding councils) and Conselhos de Acompanhamento e Controle Social do Fundeb (CACS-Fundeb) (Fundeb's monitoring and social accountability councils). The legislation states that municipalities cannot receive resources from the federal government designated to the programs PNAE, PNATE, and Fundeb if these councils are not established and operating.

These councils are spaces for participation, with the aim of monitoring and evaluating the implementation of public policies (Alencar, 2014). CAE and CACS-Fundeb are responsible for analyzing the accountability and results achieved by the programs PNAE, PNATE, and Fundeb.

Therefore, it is assumed that:

$\mathbf{H}_{4}$ : The activities of CAE and CACS-Fundeb in monitoring and providing social accountability in the implementation of PNAE, PNATE, and Fundeb, reduce corruption and mismanagement in public spending on basic education.

Finally, observing the contribution by Ferraz and Finan (2011), for voters to be able to access the information about the management of public resources, it is crucial to have media (radio, television, internet, and newspapers) able to report to the population.

Thus, it is possible to assume that:

$\mathbf{H}_{5}$ : Municipalities with a more significant number of local media tend to have less corruption and mismanagement regarding public spending on basic education. 


\section{METHODOLOGY}

\subsection{Data sources and sample}

The PFSP inspection reports were used as a database for this research. The PFSP was created in 2003 by CGU to oversee the use of federal public resources in Brazilian municipalities. The selection of these municipalities was random, conducted through public draws carried out by the state-owned bank Caixa Econômica Federal (CEF). Other data sources were the websites of the Federation of Industries of the State of Rio de Janeiro (FIRJAN), the Brazilian Institute of Geography and Statistics (IBGE), the Superior Electoral Court (TSE) and the National Treasury Secretariat (STN).

The universe of analysis was formed by 323 Brazilian municipalities that received transfers from the Ministry of Education (MEC), which were selected by CGU and inspected from the $35^{\text {th }}$ to the $40^{\text {th }}$ edition of PFSP (from 2011 to 2015). Some of the municipalities were disregarded due to the unavailability of data, forming a final sample of 306 municipalities, which do not repeat over the period analyzed (cross-sectional data structure). The actions of the Ministry of Education analyzed in this research were the Programa Nacional de Apoio ao Transporte Escolar (PNATE) (a national program of school transportation), the Programa Nacional de Alimentação Escolar (PNAE) (national school feeding program), and the Fundeb.

\subsection{Measurement of corruption and mismanagement}

To interpret and classify the findings of the PFPS inspection reports, in 'corruption' or 'mismanagement', the study used the categorical technic of content analysis (Bardin, 1977). The categories were developed by the Center for Politics and Economics in the Public Sector Studies (Cepesp) of the Fundação Getulio Vargas (FGV) and adapted for this research. Box 1 presents the description and the respective number of observations in each category.

BOX 1

\section{CATEGORIES OF CORRUPTION AND MISMANAGEMENT}

\begin{tabular}{|c|c|c|c|}
\hline Construct & Components & Description & \\
\hline \multirow{6}{*}{$\begin{array}{l}\text { Bids and } \\
\text { contracts I }\end{array}$} & & Indication of corruption & municipalities \\
\hline & $\mathrm{BID}-\mathrm{C} 1$ & Indication of fraud in the elaboration of the bid's public notice & 447 \\
\hline & BID-C2 & Indication of fraud during the procurement process & 326 \\
\hline & BID-C3 & $\begin{array}{l}\text { Indication of fraud in the purchase of goods and services through } \\
\text { bidding waiver or unenforceability }\end{array}$ & 167 \\
\hline & BID-C4 & $\begin{array}{l}\text { Overprice: occurs when contracted prices are higher than the } \\
\text { regular market prices, or when the quantity contracted exceeds the } \\
\text { needs of the municipality (in this case, the payment for the good or } \\
\text { service was not made yet) }\end{array}$ & 49 \\
\hline & CONT-1 & $\begin{array}{l}\text { Indication of fraud in the officialization and implementation of the } \\
\text { contract, and in contract amendments }\end{array}$ & 266 \\
\hline
\end{tabular}




\begin{tabular}{|c|c|c|c|}
\hline Construct & Components & Description & Number of \\
\hline \multirow{5}{*}{ Embezzlement } & & Indication of corruption & municipalities \\
\hline & EMB-C1 & $\begin{array}{l}\text { Overbilling: occurs when paid prices are higher than the regular } \\
\text { market prices, or when the quantity contracted and paid exceeds } \\
\text { the needs of the municipality }\end{array}$ & 104 \\
\hline & EMB-C2 & Irregular or non-certified invoices & 47 \\
\hline & EMB-C3 & $\begin{array}{l}\text { Unverified payments: any expense without proof of the purchase or } \\
\text { appropriate supply. Evidence of expenses without proof, observed by } \\
\text { auditors of the CGU }\end{array}$ & 365 \\
\hline & & Indication of mismanagement & $\begin{array}{l}\text { Number of } \\
\text { municipalities }\end{array}$ \\
\hline \multirow{3}{*}{$\begin{array}{c}\text { Bids and } \\
\text { contracts II }\end{array}$} & BID-MM1 & Absence of publicity, or inadequate publicization & 195 \\
\hline & BID-MM2 & Errors observed in the procurement of goods and services & 165 \\
\hline & PER-1 & Failing in achieving goals & 192 \\
\hline \multirow{4}{*}{ Performance } & PER-2 & $\begin{array}{l}\text { Unfinished works and projects (or delivered without observing } \\
\text { contractual specifications or conditions); Goods and services } \\
\text { delivered without observing contractual specifications or conditions }\end{array}$ & 108 \\
\hline & PER-3 & $\begin{array}{l}\text { Absence of appropriate financial procedure, incurring in payment } \\
\text { of interests, fines, fees, as well as irregularities regarding bank } \\
\text { activities }\end{array}$ & 133 \\
\hline & PER-4 & Absence (or errors) of accountability & 32 \\
\hline & PER-5 & $\begin{array}{l}\text { Absence (or errors) in control and/or monitoring of adequate service } \\
\text { rendering, or in implementation of works by the local government }\end{array}$ & 175 \\
\hline \multirow{5}{*}{ Infrastructure } & INFRA-1 & Precarious or idle service facilities or means & 552 \\
\hline & INFRA-2 & Lack of inputs and other materials & 285 \\
\hline & INFRA-3 & Problems to control the stock of inputs and other materials & 588 \\
\hline & INFRA-4 & Inadequate inputs maintenance & 587 \\
\hline & $\mathrm{HR}-1$ & Problems related to working hours & 23 \\
\hline \multirow{3}{*}{$\begin{array}{l}\text { Human } \\
\text { Resources }\end{array}$} & HR-2 & Problems related to employees training and working conditions & 81 \\
\hline & HR-3 & $\begin{array}{l}\text { Team (lack of excess of personnel, irregular contracting, } \\
\text { accumulation of work or deviation from the agreed role, } \\
\text { inconsistency between the real information about personnel and the } \\
\text { information released to the public, outdated personnel database) }\end{array}$ & 354 \\
\hline & HR-4 & Irregularities related to salaries and labor taxes & 79 \\
\hline \multirow{2}{*}{ Others } & NAA & $\begin{array}{l}\text { Non-authorized application of funds to other activities related to } \\
\text { education and/or ministries }\end{array}$ & 256 \\
\hline & DOC & $\begin{array}{l}\text { Incomplete, inadequate, or absent documentation related to } \\
\text { bureaucratic issues (not fraud) }\end{array}$ & 57 \\
\hline
\end{tabular}

Source: Adapted from CEPESP-FGV as cited in Lopes (2011, p. 106). 


\subsection{Variables and regression model}

Box 2 shows the variables used in the study, chosen based on the literature and database availability.

\begin{tabular}{|c|c|c|c|c|}
\hline Category & Variable & Description & $\begin{array}{l}\text { Expected } \\
\text { relation }\end{array}$ & Source \\
\hline \multirow{2}{*}{ Dependent } & $\begin{array}{l}\text { Corruption } \\
\text { (corrup) }\end{array}$ & $\begin{array}{c}\text { Number of irregularities identified by } \\
\text { auditors of the CGU, classified in this } \\
\text { study as corruption }\end{array}$ & - & CGU \\
\hline & $\begin{array}{l}\text { Mismanagement } \\
\text { (mis_man) }\end{array}$ & $\begin{array}{c}\text { Number of irregularities identified by } \\
\text { auditors of the CGU, classified in this } \\
\text { study as mismanagement }\end{array}$ & - & CGU \\
\hline \multirow{2}{*}{ Political factors } & $\begin{array}{l}\text { Reelection } \\
\text { (mayor_ree) }\end{array}$ & $\begin{array}{c}\text { Dummy variable. Indicates if the } \\
\text { mayor was in their first or second } \\
\text { mandate }(1=\text { reelected; } 0=\text { first } \\
\text { term })\end{array}$ & Positive & IBGE \\
\hline & $\begin{array}{l}\text { Number of parties } \\
\text { (nop) }\end{array}$ & $\begin{array}{l}\text { It is calculated by dividing } 1 \text { by the } \\
\text { sum of the square of the proportions } \\
\text { of votes obtained by each mayoral } \\
\text { candidate }\end{array}$ & Negative & TSE \\
\hline $\begin{array}{l}\text { Socioeconomic } \\
\text { factor }\end{array}$ & $\begin{array}{l}\text { Voters' profile } \\
\text { (FMDI) }\end{array}$ & $\begin{array}{l}\text { Degree of municipal development, } \\
\text { considering three parameters: } \\
\text { employment and income, education, } \\
\text { and health }\end{array}$ & Negative & $\begin{array}{c}\text { Índice de } \\
\text { Desenvolvimento } \\
\text { Municipal (municipal } \\
\text { development index) } \\
\text { (Federação das Indústrias } \\
\text { do Estado do Rio de } \\
\text { Janeiro [FIRJAN], 2018) }\end{array}$ \\
\hline \multirow[t]{2}{*}{$\begin{array}{l}\text { Social } \\
\text { accountability } \\
\text { and access to } \\
\text { information }\end{array}$} & $\begin{array}{l}\text { Social } \\
\text { accountability } \\
\text { (soc_accoun) }\end{array}$ & $\begin{array}{l}\text { Dummy variable. Indicates if the } \\
\text { council is active or not ( } 1=\text { non- } \\
\text { active council; } 0=\text { active council). } \\
\text { Social accountability exercised by the } \\
\text { council was considered active when } \\
\text { the report of the inspection did not } \\
\text { mention problems in the work of the } \\
\text { CAE and CACS-Fundeb }\end{array}$ & Positive & CGU \\
\hline & $\begin{array}{l}\text { Local media } \\
\text { (media_loc) }\end{array}$ & $\begin{array}{l}\text { It indicates the quantity of local } \\
\text { media present in the municipality. It } \\
\text { varies from } 0 \text { (no local media) and } \\
03 \text { (presence of radio, television, and } \\
\text { Internet) }\end{array}$ & Negative & IBGE \\
\hline
\end{tabular}




\begin{tabular}{|c|c|c|c|c|}
\hline Category & Variable & Description & $\begin{array}{l}\text { Expected } \\
\text { relation }\end{array}$ & Source \\
\hline \multirow{7}{*}{ Control } & $\begin{array}{c}\text { Received transfers } \\
\text { (transf) }\end{array}$ & $\begin{array}{l}\text { Total amount of federal resources } \\
\text { transferred to the municipality } \\
\text { through the FNDE, divided by the size } \\
\text { of the population. }\end{array}$ & Positive & $\begin{array}{l}\text { Finanças do Brasil } \\
\text { (FINBRA) - STN }\end{array}$ \\
\hline & $\begin{array}{c}\text { Number of service } \\
\text { orders } \\
(s o)\end{array}$ & $\begin{array}{l}\text { It is the number of actions inspected } \\
\text { by the CGU in the municipalities }\end{array}$ & Positive & CGU \\
\hline & $\begin{array}{l}\text { Region } \\
\text { (d_reg) }\end{array}$ & $\begin{array}{l}\text { Dummy variable. Designates the } \\
\text { Brazilian political-administrative } \\
\text { region where the municipality is } \\
\text { located ( } 1=\text { North and Northeast; } 0 \\
=\text { Central-West, Southeast, South) }\end{array}$ & Positive & IBGE \\
\hline & $\begin{array}{l}\text { Manager } \\
\text { education } \\
\text { (man_edu) }\end{array}$ & $\begin{array}{l}\text { Education level of the public official } \\
\text { responsible for the municipal } \\
\text { secretary of education ( } 1= \\
\text { elementary and high school; } 2= \\
\text { higher education; } 3=\text { graduate } \\
\text { degree) }\end{array}$ & Negative & IBGE \\
\hline & $\begin{array}{l}\text { Administrative } \\
\text { improvement } \\
\text { (adm_impro) }\end{array}$ & $\begin{array}{l}\text { Dummy variable. Indicates if the } \\
\text { public official responsible for the } \\
\text { municipal secretary of education } \\
\text { invested to improve the secretary's } \\
\text { administration (1 = yes; } 2=\text { no) }\end{array}$ & Negative & IBGE \\
\hline & $\begin{array}{l}\text { Community } \\
\text { participation } \\
\text { in the school's } \\
\text { administration } \\
\text { (comm_part) }\end{array}$ & $\begin{array}{l}\text { Dummy variable. Indicates if the } \\
\text { local community participated in the } \\
\text { school's administration ( } 1=\text { yes; } 0 \\
=\text { no) }\end{array}$ & Negative & IBGE \\
\hline & $\begin{array}{l}\text { Demographic } \\
\text { density } \\
\text { (dens) }\end{array}$ & $\begin{array}{l}\text { Indicates the number of inhabitants } \\
\text { per km² }\end{array}$ & Positive & IBGE \\
\hline
\end{tabular}

Source: Elaborated by the authors.

Because the dependent variables only assume integer and positive values, it was necessary to use regression models for counting data. The goodness-of-fit test suggests that the negative binomial regression model was the best fit to the data in this research (Fávero, 2015; Long \& Freese, 2001). Thus, the estimated model can be represented by the following equation:

$\lambda_{i}=e^{(\alpha+\beta 1)}$ Political factors $_{i}+\beta_{2}$ Socioeconomic factor $_{i}+\beta_{3}$ Social accountability and access to information $_{i}$ $+\beta_{4}$ Control variables ${ }_{i}+\varepsilon_{i}$

where $\lambda$ corresponds to the expected number of irregularities classified as corruption or mismanagement of a municipality $i$; $\alpha$ represents the constant; $\beta\left(_{1 \ldots n}\right)$ are the estimated parameters for each explanatory variable; $\varepsilon_{i}$ is the robust clustered error term. 


\section{RESULTS}

\subsection{Descriptive statistics}

Table 1 shows that, on average, six irregularities classified as corruption and thirteen as mismanagement were found in the municipalities of the sample. The municipality with the highest incidence of corruption (45) was Aliança (PE), and the municipality with the highest incidence of mismanagement (66) was Itaipava do Grajaú (MA). Moreover, the comparison of the standard deviation with the average, shows different degrees of dispersion of the variables 'corruption' and 'mismanagement' in the municipalities.

In the case of quantitative independent variables, the municipal elections of 2008 and 2012 had, on average, two mayoral candidates, approximately. However, through the maximum and minimum values of the variable 'number of parties', it was possible to observe municipalities that had high party fragmentation, such as Marapanim (PA) (number of parties = 4.26); and others where there was only one party participating in the election: Aliança (PE), Croatá (CE), Ibirapitanga (BA), Paripueira (AL), and Poranga (CE).

Descriptive statistics on voters' profile indicate that, in general, the education, health, and income parameters showed a regular level of development in the municipalities of the sample. However, it was possible to observe municipalities with low development index - such as Tremedal (BA), when compared to those with high development index, such as Pontes Gestal (SP).

Two actions, on average, were inspected in each municipality. The average amount per capita, transferred to municipalities through the FNDE, was BRL 132.53. There was, however, a large dispersion in the amounts received. For example, in Pedra Branca do Amapari (AP), the amount per capita received was of less than BRL 25.00, whereas in Tupirama (TO), it was of over BRL 660.00.

\section{TABLE 1 DESCRIPTION OF QUANTITATIVE VARIABLES}

\begin{tabular}{lcccc}
\hline Variables & Average & Standard deviation & Minimum & Maximum \\
\hline Corruption & 5.79 & 7.67 & 0 & 45 \\
Mismanagement & 12.62 & 12.13 & 0 & 4.26 \\
Number of parties & 2.04 & 0.52 & 1 & 0.8883 \\
Voters' profile & 0.6433 & 0.1047 & 0.3712 & 3 \\
Local media & 1.32 & 0.90 & 0 & $3 \$ 63.36$ \\
Received transfers & 132.53 & 69.46 & 1 & 1010.69 \\
Number of actions inspected & 2.22 & 0.66 & 0.33 &
\end{tabular}

Source: Elaborated by the authors. 
Table 2 shows data on municipal managers, voters, and municipal councils. It was observed that most of the audited municipalities were administered by mayors in their first mandate (63.73\%). As for community participation, Table 2 shows that in $65.36 \%$ of municipalities, the population participated in the administration of schools. Regarding the municipal councils, it was observed that the Conselhos Municipais de Alimentação Escolar (CAE) (municipal school feeding councils) and Conselhos de Acompanhamento e Controle Social do Fundeb (CACS-Fundeb) (Fundeb's monitoring and social accountability councils), in $74.84 \%$ of the municipalities analyzed, did not monitor and supervise the implementation of PNAE, PNATE, and Fundeb.

Table 2 describes the statistics of variables used as a proxy for the administrative capacity of the secretaries of education in the municipalities of the sample. In general, it is noted that more than $67 \%$ of the public officials responsible for these secretaries held a graduate degree, and $58.17 \%$ of them invested in improving the administration of the secretaries. Also, 52\% of the municipalities are located in the North and Northeast regions of Brazil.

\section{TABLE 2 DESCRIPTION OF QUALITATIVE VARIABLES}

\begin{tabular}{|c|c|c|c|}
\hline Variables & Variables description & Number of municipalities & Percentage \\
\hline \multirow{2}{*}{ Reelected } & Mayor reelected & 111 & 36.27 \\
\hline & Mayor in their first mandate & 195 & 63.73 \\
\hline \multirow{2}{*}{ Social accountability } & Non-active council & 229 & 74.84 \\
\hline & Active council & 77 & 25.16 \\
\hline \multirow{2}{*}{ Region } & North and Northeast & 158 & 51.63 \\
\hline & Central-West, Southeast, and South & 148 & 48.37 \\
\hline \multirow{3}{*}{$\begin{array}{l}\text { Education of the public official } \\
\text { responsible for the municipal secretary } \\
\text { of education }\end{array}$} & High school & 10 & 3.27 \\
\hline & Higher education & 90 & 29.41 \\
\hline & Graduate degree & 206 & 67.32 \\
\hline \multirow{2}{*}{$\begin{array}{l}\text { Administrative improvement of the } \\
\text { secretary of education }\end{array}$} & Yes & 178 & 58.17 \\
\hline & No & 128 & 41.83 \\
\hline \multirow{2}{*}{$\begin{array}{l}\text { Community participation in the } \\
\text { school's administration }\end{array}$} & Yes & 200 & 65.36 \\
\hline & No & 106 & 34.64 \\
\hline
\end{tabular}

Source: Elaborated by the authors

\subsection{Negative binomial regression}

The results of the estimates of negative binomial regression models are presented in Table 3 . The first model analyzes the effect of political and socioeconomic factors on the incidence of corruption in public spending on basic education. The second model verifies the effect of these factors on mismanagement regarding investments in basic education. Finally, the $x^{2}$ test results indicate that the two estimated models are statistically valid at a significance level of $1 \%$. 
RAP | Corruption and mismanagement in spending on education: socioeconomic and political factors

\section{TABLE 3 ESTIMATION OF NEGATIVE BINOMIAL REGRESSION MODELS}

\begin{tabular}{|c|c|c|c|c|}
\hline \multirow{2}{*}{ Coefficients } & \multicolumn{2}{|r|}{ Model 1} & \multicolumn{2}{|c|}{ Model 2} \\
\hline & Corruption & Estimated incidence rate & Mismanagement & Estimated incidence rate \\
\hline \multirow{2}{*}{ Reelection } & 0.1309 & 1.1399 & -0.0396 & -0.9611 \\
\hline & $(0.000)^{\star \star \star}$ & $(0.000)^{\star \star \star}$ & $(0.496)$ & $(0.496)$ \\
\hline \multirow{2}{*}{ Number of parties } & -0.0335 & -0.9671 & 0.1125 & 1.1191 \\
\hline & $(0.880)$ & $(0.880)$ & (0.125) & (0.125) \\
\hline \multirow{2}{*}{ Voters' profile } & -1.6801 & -0.1864 & -1.6905 & -0.1844 \\
\hline & (0.209) & (0.209) & $(0.001)^{\star \star \star}$ & $(0.001)^{\star \star \star}$ \\
\hline \multirow{2}{*}{ Social accountability } & 0.5429 & 1.7210 & 0.5082 & 1.6622 \\
\hline & $(0.000)^{\star \star \star}$ & $(0.000)^{\star \star \star}$ & $(0.000)^{\star \star \star}$ & $(0.000)^{\star \star \star}$ \\
\hline \multirow{2}{*}{ Local media } & 0.0293 & 1.0297 & 0.0463 & 1.0474 \\
\hline & (0.773) & (0.773) & (0.382) & (0.382) \\
\hline \multirow{2}{*}{ Received transfers } & 0.0007 & 1.0007 & -0.0001 & -0.9999 \\
\hline & $(0.256)$ & $(0.256)$ & $(0.604)$ & $(0.604)$ \\
\hline \multirow{2}{*}{$\begin{array}{l}\text { Number of inspected } \\
\text { actions }\end{array}$} & 0.7118 & 2.0376 & 0.3345 & 1.3972 \\
\hline & $(0.000)^{\star \star \star}$ & $(0.000)^{\star \star \star}$ & $(0.001)^{\star \star \star}$ & $(0.001)^{\star \star \star}$ \\
\hline \multirow{2}{*}{ Region } & 0.5305 & 1.6999 & 0.6225 & 1.8636 \\
\hline & $(0.048)^{\star \star}$ & $(0.048)^{\star \star}$ & $(0.000)^{* * \star}$ & $(0.000)^{\star \star \star}$ \\
\hline \multirow{2}{*}{ Manager's education } & -0.1192 & -0.8876 & -0.0836 & -0.9198 \\
\hline & $(0.088)^{\star}$ & $(0.088)^{\star}$ & $(0.009)^{\star \star \star}$ & $(0.009)^{\star \star \star}$ \\
\hline \multirow{2}{*}{$\begin{array}{l}\text { Administrative } \\
\text { improvements }\end{array}$} & -0.1592 & -0.8528 & 0.0248 & 1.0251 \\
\hline & $(0.366)$ & (0.366) & (0.704) & (0.704) \\
\hline \multirow{2}{*}{ Community participation } & -0.0206 & 0.9796 & -0.0016 & -0.9984 \\
\hline & (0.843) & (0.843) & (0.990) & (0.990) \\
\hline \multirow{2}{*}{ Demographic density } & 0.0002 & 1.0002 & 0.0008 & 1.0008 \\
\hline & $(0.716)$ & $(0.716)$ & $(0.015)^{\star \star}$ & $(0.015)^{\star \star}$ \\
\hline Constant & 0.4990 & 1.6470 & 1.8585 & 6.4142 \\
\hline Prob $>x^{2}$ & \multicolumn{2}{|r|}{0.000} & \multicolumn{2}{|r|}{0.000} \\
\hline Pseudo $\mathrm{R}^{2}$ & \multicolumn{2}{|r|}{0.0844} & \multicolumn{2}{|c|}{0.0867} \\
\hline
\end{tabular}

Source: Elaborated by the authors.

Notes: Values in parenthesis indicate estimated robust clustered errors

Significance level at ${ }^{* *} 1 \%$; ${ }^{* *} 5 \%$; and ${ }^{*} 10 \%$. 
When analyzing the relationship between political factors and the waste of resources classified as corruption, the results indicated that the mayor was less likely to present corrupt behavior when in their first term. These findings are similar to those of Albuquerque and Ramos (2006), Ferraz and Finan (2011), Batista (2013), Dias (2016), and Benito et al. (2018), who consider the possibility of reelection as a mechanism of constraint to the corrupt behavior of political agents.

Mayors who were likely to be reelected were supposed to have incentives to oversee the work of bureaucrats in the application of investment in basic education, minimizing negligence and unpreparedness of these professionals regarding best managerial practices. However, it was possible to see that reelection and electoral competition did not affect the incidence of mismanagement in public spending on basic education. Therefore, the first hypothesis assuming a positive relationship between corruption and mismanagement, and mayors in the second mandate was confirmed for corruption, but not for mismanagement.

As for the influence of socioeconomic factors on the number of irregularities that occurred in public spending on basic education, it appears that the variable that indicates the voters' profile was not significant to explain the corrupt behavior of mayors. In turn, this proxy was significantly related to the number of irregularities classified as mismanagement.

The observation of the results in model 2 indicates that keeping the other factors constant, when voters had higher income and education levels, the mismanagement incidence rate was, on average, 81.56\% lower. This result partially corroborates the third hypothesis presented here.

Thus, there is evidence that more politically sophisticated populations were more likely to be informed and denounce illegal actions from mayors. Against this backdrop, it is possible to say that, when faced with voters with a politically sophisticated profile, mayors would have more incentives to implement a management style privileging the proper public spending on basic education.

Another aspect analyzed in this study was the influence of civil society's participation mechanisms on the waste of public resources. The likelihood of the local authority to behave corruptly and incur in mismanagement was estimated to have increased by $72.10 \%$ and $66.22 \%$, respectively, when CAE and/ or CACS-Fundeb did not oversee the PNAE, PNATE, and Fundeb. The positive relationship between the incidence of corruption and mismanagement with non-active councils is in line with the fourth hypothesis presented, corroborating the findings of Campos and Castelar (2013) and Dias (2016).

This research used independent control variables to control the effect of other factors on the occurrence of waste in public spending on basic education. Empirical evidence reveals significant results for the variables: a) "number of actions inspected;" b) "region;" c) "manager's education;" and d) "demographic density."

The variable "number of actions inspected" had a positive and statistically significant coefficient at the $1 \%$ level in both models. There is evidence that an increase of one unit in the number of supervised actions increases the probability of corruption incidence by $103.76 \%$ and the likelihood of mismanagement in public spending on basic education by $39.72 \%$.

Another control variable that showed a positive and statistically significant relationship in the two estimated models was the variable 'region.' It is estimated that, in the municipalities located in the North and Northeast regions of Brazil, the chances of corruption and mismanagement were, respectively, $69.99 \%$ and $86.36 \%$ higher when compared to the municipalities located in the other Brazilian regions. 
This result can be explained, according to Vieira (2011) and Lopes (2011), by the characteristics of the municipalities located in the North and Northeast. In general, these municipalities present characteristics that favored dishonest behavior and inadequate management of federal resources. They received from the federal government through the FNDE, on average, transfers of BRL 137.50 per capita to spend on basic education. Also, these municipalities presented, on average, regular development in the areas of education, health, and population's income. In $84.18 \%$ of the municipalities in the North and Northeast of Brazil, the councils did not oversee the implementation of PNAE, PNATE, and Fundeb.

Regarding the demographic density of the municipalities, Table 3 shows that this variable had a positive and significant relationship with the incidence of mismanagement. This result also corroborates the findings of Campos and Castelar (2013).

Finally, as recommended by Lopes (2011), this study included control variables in the model, which explore specific characteristics of the area of education: a) "manager's education;" b) "administrative improvements;" and c) "community participation." Only the first variable, "manager's education," presented significant results. Thus, the higher the level of education of the manager responsible for the municipal secretary of education, the lower the incidence of corruption and mismanagement in public spending on basic education in municipalities.

\section{FINAL CONSIDERATIONS}

This study analyzed the political and socioeconomic factors that influenced the incidence of corruption and mismanagement in public spending on basic education in Brazilian municipalities. The research adopted descriptive procedures and negative binomial regression models.

The findings were interpreted based on the Public Choice Theory. They pointed out a significant relationship between political and socioeconomic factors and mechanisms of social participation; and the waste of resources in public spending on basic education in Brazilian municipalities.

PCT states that politicians make decisions based on their quest for votes, which lead them to positions of power and keep them there. Therefore, electoral circumstances have an important influence on politicians' decisions about engaging in corruption activities, particularly involving public spending in basic education.

Regarding the irregularities classified as mismanagement, the findings confirmed the hypothesis that the voters' profile may influence the style of management adopted by the political agent. The results showed that when voters were more politically sophisticated, the incidence of mismanagement was lower. This finding supports the notion that society must monitor and control the management of public resources intended for basic education, to ensure that such resources meet the demands of this area.

In addition, corroborating the assumptions of the PCT, the results confirmed the hypotheses that the ineffectiveness of CAE and CACS-Fundeb increases the likelihood of mismanagement and corruption in the implementation of PNAE, PNATE, and Fundeb. However, it is necessary to invest in training council members and offer infrastructure for the CAE and CACS-Fundeb to allow counselors to effectively monitor the performance of public agents in spending on basic education. 
By analyzing in detail the incidence of corruption and mismanagement in education, this research contributes to the literature that investigates the occurrence of waste of public resources. This endeavor may help to design public policies less susceptible to the incidence of deviations, as recommended by Lopes (2011).

Nevertheless, the findings obtained regarding the occurrence of mismanagement stand out. Compared to acts of corruption, this type of irregularity occurred to a greater extent in public spending on basic education. This indicates that most of the waste of public resources was not related to a direct benefit to a public official. The waste was a consequence of negligence and unpreparedness of public agents, who wrongly invested public resources jeopardizing the delivery of services in the area of education.

In addition, considering that part of the first hypothesis about the relationship between mismanagement and the politician's mandate was not confirmed, it is possible to assume that structural deficiencies in human, technical, and financial resources in the municipalities may have limited the performance of public managers when applying the funds designated to PNAE, PNATE and Fundeb. This result suggests that future research analyzes the influence of the structural characteristics of municipalities on mismanagement in public spending. Among the structural characteristics to be analyzed, the level of education of civil servants can be highlighted, seeking to verify the hypothesis that more qualified civil servants would be less likely to make mistakes when managing public resources.

As for the relationship between voters' profile and corruption in public spending on basic education, the study observed that the political sophistication of voters did not influence the corrupt behavior of political agents as it did in the case of mismanagement. An explanation for this phenomenon may be that even the most educated and well-prepared voters were not knowledgeable enough regarding administrative processes (such as public procurement, for instance) to detect the types of irregularities classified as corruption.

Identifying this type of waste is a task that demands frequent inspection from agencies of control and punishment (courts of auditors, comptroller general, Federal Police, and Ministry of Justice), since these bodies have the appropriate tools and training to identify acts of corruption. Thus, future research could examine the relationship between the actions of agencies of control and punishment, and the corrupt behavior of political agents. 


\section{REFERENCES}

Albuquerque, B., \& Ramos, F. (2006). Análise teórica e empírica dos determinantes da corrupção na gestão pública municipal. In Anais do $34^{\circ}$ Encontro Nacional de Economia. Salvador, BA.

Alencar, J. (2014). Participação social: institucionalização e integração ao ciclo de políticas públicas. In M. Monasterio, \& S. Soares (Coords.), Brasilem desenvolvimento 2014: Estado, planejamento e políticas públicas (pp. 261-278). Brasília, DF: Ipea

Bardin, L. (1977). Análise de conteúdo. Lisboa, Portugal: Ed. 70.

Batista, M. (2013). Incentivos da dinâmica política sobre a corrupção: reeleição, competitividade e coalizões nos municípios brasileiros. Revista Brasileira de Ciências Sociais, 28(82), 87-106.

Benito, B., Guillamón, M., Ríos, A., \& Bastida, F. (2018). Can salaries and re-election prevent political corruption? An empirical evidence. Revista de Contabilidad: Spanish Accounting Review, 21(1), 19-27.

Borsani, H. (2004). Relações entre política e economia: teoria da escolha pública. In C. Biderman, $\&$ P. Arvate (Coords.), Economia do setor público no Brasil (pp. 103-125). Rio de Janeiro, RJ: Elsevier.

Campos, F. A., \& Castelar, L. I. (2013). Avaliação da corrupção municipal a partir de micro dados. In Anais do 41o Encontro Nacional de Economia. Foz do Iguaçu, PR.

Carreirão, Y. (2000). A decisão do voto nas eleições presidenciais no Brasil (1989 a 1998): a importância do voto por avaliação de desempenho (Doctoral Dissertation). São Paulo, SP: Universidade de São Paulo.

Constituição da República Federativa do Brasil, de 5 de outubro de 1988. (1988). Brasília, DF.

Controladoria-Geral da União. (2016). Balanço de Ações da CGU. Retrieved from http://www.cgu.gov.br/ sobre/institucional/eventos/anos-anteriores/2016/ dia-internacional-contra-acorrupcao/arquivos/ dicc2016_cgu_2016.pdf

Controladoria-Geral da União. (n.d.). Programa de Fiscalização por Sorteios Públicos. Retrieved from http://www.cgu.gov.br/assuntos/auditoria-efiscalizacao/programa-de-fiscalizacao-em-entes- federativos

Del Monte, A., \& Papagni, E. (2007). The determinants of corruption in Italy: regional panel data analysis. European Journal of Political Economy, 23(2), 379396.

Dias, L. (2016). Fatores que impactam na corrupção e na ineficiência relacionadas à aplicação de recursos da saúde pública municipal (Doctoral Dissertation). Brasília, DF: Universidade de Brasília.

Fávero, L. (2015). Análise de dados: modelos de regressão com Excel, Stata e SPSS. Rio de Janeiro, RJ: Campus Elsevier.

Federação das Indústrias do Estado do Rio de Janeiro. (2018). Indice FIRJAN de Desenvolvimento Municipal. Retrieved from https://www.firjan.com. br/ifdm/

Ferraz, C., \& Finan, F. (2011). Electoral accountability and corruption: evidence from the audits of local governments. American Economic Review, 101(4), 1274-1311.

Ferraz, C., Finan, F., \& Moreira, D. (2008). Corrupção, má gestão, e desempenho educacional: evidências a partir da fiscalização dos municípios. In Anais do 36 Encontro Nacional de Economia. Salvador, BA.

Ferraz, C., Finan, F., \& Moreira, D. (2012). Corrupting learning: evidence from missing federal education funds in Brazil. Journal of Public Economics, 96(9), 712-726.

Figueiredo, M. (2008). A decisão do voto: democracia e racionalidade. Belo Horizonte, MG: Ed. UFMG.

Fundo Nacional de Desenvolvimento da Educação. (2007). Sobre o Fundeb. Brasília, DF: Author.

Instituto Brasileiro de Geografia e Estatística. Perfil dos Municípios. Retrieved from http://www.ibge. gov.br/home/

Instituto Nacional de Estudos e Pesquisas Educacionais Anísio Teixeira. (2014). Indicadores financeiros educacionais. Retrieved from http:// portal.inep.gov.br/indicadores-financeiroseducacionais

Instituto Nacional de Estudos e Pesquisas Educacionais Anísio Teixeira. (2016). Brasil no PISA 2015: análises e reflexões sobre o desempenho dos estudantes brasileiros. Retrieved from http://download.inep. 
gov.br/acoes_internacionais/pisa/resultados/2015/ pisa2015_completo_final_baixa.pdf

Laurinho, I., Dias, L., \& Mattos, C. (2017). Corrupção e ineficiência em licitações de governos locais e desenvolvimento humano: novas reflexões. Revista de Contabilidade e Organizações, 30, 57-70.

Lio, M., Liu, M., \& Ou, Y. (2011). Can the internet reduce corruption? A cross-country study based on dynamic panel data models. Government Information Quarterly, 28, 47-53.

Long, J., \& Freese, J. (2001). Regression models for categorical dependent variables using Stata. College Station, TX: Stata Press.

Lopes, M. (2011). Corrupção: estudo sobre as formas de mensuração, seus determinantes e perspectivas sobre as formas de combate (Doctoral Dissertation). São Paulo, SP: Fundação Getulio Vargas.

Organisation for Economic Co-Operation and Development. (2016). Programme for International Student Assessment (PISA): results from PISA 2015. Retrieved from https://www.oecd.org/pisa/PISA2015-Brazil-PRT.pdf

Pereira, F. (2013). Sofisticação política e opinião pública no Brasil: revisitando hipóteses clássicas. Opinião Pública, 19(2), 291-319.

Pires, R., \& Vaz, A. (2012). Participação social como método de governo? Um mapeamento das "interfaces socioestatais" nos programas federais (Texto para Discussão IPEA n. 1707). Brasília, DF: Instituto de Pesquisa Econômica Aplicada.
Rua, M., \& Aguiar, A. (1995). A política industrial no Brasil, 1985-1992: políticos, burocratas e interesses organizados no processo de policy-making. Planejamento e Políticas Públicas, 12, 233-277.

Secretaria do Tesouro Nacional. Finanças do Brasil - Dados Contábeis dos Municípios. Retrieved from http://www.tesouro.fazenda.gov.br/contas-anuais.

Shughart, W., II. (2007). Public choice (The Library of Economics and Liberty). Retrieved from http:// www.econlib.org/library/Enc/PublicChoice.html

Silva, M. (2001). A economia política da corrupção no Brasil. São Paulo, SP: Ed. Senac.

Sodré, A., \& Alves, M. (2010). Relação entre emendas parlamentares e corrupção municipal no Brasil: estudo dos relatórios do programa de fiscalização da Controladoria-Geral da União. Revista de Administração Contemporânea, 14(3), 414-433.

Transparency International. (2018). Anti-corruption glossary: corruption. Retrieved from https://www. transparency.org/glossary/term/corruption

Tribunal Superior Eleitoral. Eleições anteriores. Retrieved from http://www.tse.jus.br/eleicoes/ eleicoes-anteriorese

Vieira, J. (2011). O impacto das capacidades institucionais do setor público: um estudo exploratório sobre as causas e efeitos das improbidades na administração pública municipal brasileira. In Anais do 60 Concurso de Monografias da CGU. Brasília, DF. 


\section{Daniele Silva Rodrigues}

https://orcid.org/0000-0002-6672-1236

$\mathrm{PhD}$ student in accounting and control in the Graduate and Research Center in Accounting and Control of the Federal University of Minas Gerais (CEPCON-UFMG). E-mail: silvar.daniele@gmail.com

\section{Walmer Faroni}

https://orcid.org/0000-0002-9655-8935

$\mathrm{PhD}$ in administration and public finances; Professor of the Graduate Program in Administration of the Federal University of Viçosa (UFV). E-mail: walmerfaroni@gmail.com

\section{Nálbia de Araújo Santos}

https://orcid.org/0000-0002-6259-1446

$\mathrm{PhD}$ in accounting and control; Professor of the Graduate Program in Administration of the Federal University of Viçosa (UFV). E-mail: nalbia@ufv.br

\section{Marco Aurélio Marques Ferreira}

https://orcid.org/0000-0002-9538-1699

Post-Doctoral in public administration; Professor of the Graduate Program in Administration of the Federal University of Viçosa (UFV). E-mail: marcoaurelio@ufv.br

\section{Josedilton Alves Diniz}

https://orcid.org/0000-0002-8119-3099

$\mathrm{PhD}$ in accounting and control; Auditor of the Court of Accounts of the State of Paraiba; Professor of the Graduate Program in Accounting of the Federal University of Paraíba (UFPB). E-mail: josedilton@gmail.com 